\title{
Orbital Sarcoma Clinical Distant Metastasis TNM Finding v8
}

National Cancer Institute

\section{Source}

National Cancer Institute. Orbital Sarcoma Clinical Distant Metastasis TNM Finding v8. NCI Thesaurus. Code C140834.

A clinical finding about one or more characteristics of orbital sarcoma, following the rules of the TNM AJCC v8 classification system as they pertain to distant metastases. 